Maurice A. Deane School of Law at Hofstra University Scholarly Commons at Hofstra Law

Hofstra Law Faculty Scholarship

2009

\title{
Designing Factfinding For Cross-Border Healthcare
}

Vern R. Walker

Maurice A. Deane School of Law at Hofstra University

Follow this and additional works at: https://scholarlycommons.law.hofstra.edu/faculty_scholarship

\section{Recommended Citation}

Vern R. Walker, Designing Factfinding For Cross-Border Healthcare, 3 Opinio Juris in Comparatione 1 (2009)

Available at: https://scholarlycommons.law.hofstra.edu/faculty_scholarship/634

This Article is brought to you for free and open access by Scholarly Commons at Hofstra Law. It has been accepted for inclusion in Hofstra Law Faculty Scholarship by an authorized administrator of Scholarly Commons at Hofstra Law. For more information, please contact lawcls@hofstra.edu. 


\title{
DESIGNING FACTFINDING FOR CROSS-BORDER HEALTHCARE
}

\author{
by
}

Vern R. Walker

\begin{abstract}
A critical problem in providing appropriate compensation for medical accidents in the context of crossborder healthcare is designing and supervising the factfinding processes. Numerous compensation systems in multiple jurisdictions, handling a high volume of cases, must be able to achieve outcome efficiency (neither under-compensating nor over-compensating victims), while also achieving administrative efficiency (low transaction costs). It is impossible to achieve these goals without consistent, accurate, evidence-based factfinding, particularly in an area as factually complex as medicalaccident compensation. This paper discusses a framework for producing such factfinding without creating a centralized factfinding institution, and provides examples of general principles, institutional structures, and specific types of legal rules for evidence assessment. It illustrates aspects of this framework using the National Vaccine Injury Compensation Program in the United States. Both the structure of that Program and the cases decided under it provide insights on how factfinding can be transparent, evidence-based, and coordinated, as well as (presumably) accurate, so that all potentially affected parties can be confident that the compensation system is achieving its goals.
\end{abstract}

- Professor of Law, Hofstra University School of Law, Hempstead, New York 11549, USA; vern.r.walker@hofstra.edu. The author is grateful to Hofstra University for financial and other support in the preparation of this paper. 
Vern R. Walker, Designing Factfinding...

\section{Introduction and Context: The Problem of Coordinated, Accurate Factfinding}

In July of 2008, the European Commission issued its Proposal for a Directive of the European Parliament and of the Council on the application of patients' rights in cross-border healthcare. ${ }^{1}$ The goals of the proposal include ensuring a "high level of protection of health" and establishing "a general framework for the provision of safe, high quality and efficient cross-border healthcare" in the Community. ${ }^{2}$ In connection with these goals, the Commission stated that "there is a set of operating principles that are shared by health systems throughout the Community," which include "quality, safety, [and] care that is based on evidence," among others. ${ }^{3}$ Moreover, the Commission proposed that "it is the authorities of the Member State on whose territory the healthcare is provided, who are responsible for ensuring compliance with those operating principles," in order "to ensure the confidence of patients in cross-border healthcare."4

Within this broad context, this paper focuses on medical liability and compensation for medical accidents within the cross-border context. The Commission proposed as part of its general framework that the Member State on whose territory the cross-border healthcare is provided (the "Member State of treatment") has the responsibility of ensuring (among other things) that "patients have a means of making complaints and are guaranteed remedies and compensation when they suffer harm arising from

\footnotetext{
${ }^{1}$ Commission of the European Communities, Proposal for a Directive of the European Parliament and of the Council on the application of patients' rights in cross-border healthcare SEC(2008) 2163OESEC(2008) 2164OESEC(2008) 2183OE, $\operatorname{COM}(2008) 414$ (2 July 2008).

${ }^{2}$ Id., proposed Article 1; preamble, para. (8).

${ }^{3}$ Id., preamble, para. (11).

${ }^{4} I d$.

${ }^{5}$ Id., proposed Article 4(i).
} 
Opinio Juris in Comparatione, Vol. 3/2009, Paper n. 1

the healthcare they receive." ${ }^{\prime 6}$ The Commission rightly regards effective compensation systems as essential elements of any framework whose goal is to ensure "safe, high-quality and efficient" healthcare. No healthcare system could achieve efficient outcomes if it did not internalize the true cost of healthcare accidents into the total cost of healthcare. "Outcome efficiency" means that a compensation system should neither under-compensate nor over-compensate claimants - that is, neither externalize a true healthcare cost by imposing it on individual patients, nor waste healthcare resources by giving unwarranted or excessive compensation awards. Patients should be compensated from healthcare resources (only) to the extent that they suffer a "harm arising from healthcare." Such efficient compensation would also contribute to ensuring "safe" and "high-quality" healthcare by providing an optimal level of deterrence against sub-standard healthcare services.

Achieving outcome efficiency and optimal deterrence therefore depends upon accurate factfinding about the nature, extent and causes of healthcare-related injuries. The problem addressed in this paper is how to ensure accurate factfinding within compensation systems for medical accidents within cross-border healthcare. "Factfinding" is the process of creating an evidentiary record, assessing the probative value of the evidence in the record, and using that evidence to make the findings of fact

\footnotetext{
${ }^{6} I d$., proposed Article 5(1)(d). The Commission explained in the preamble that:
}

Member States should ensure, that mechanisms for the protection of patients and the compensation for harm are in place for healthcare provided on their territory and that they are appropriate to the nature and extent of the risk. However, it is for the Member State to determine the nature and/or modalities of such a mechanism.

Id., preamble para. 16. Moreover, these compensation systems might overlap those in the Member State from which the patient comes:

Coverage for harm and compensation by the systems of the country of treatment should be without prejudice to the possibility for Member States to extend the coverage of their domestic systems to patients from their country seeking healthcare abroad, where this is more appropriate to the patient, in particular in the case of patients for whom use of healthcare in another Member State is necessary.

Id., preamble para. 15. 
Vern R. Walker, Designing Factfinding...

that determine the applicability of legal rules. The task of designing adequate factfinding processes for cross-border healthcare compensation in the European Union is complicated by at least three factors.

First, many issues of fact must be decided on a case-by-case basis. Medical cases are often complex, and resist accurate resolution for broad categories. ${ }^{7}$ For example, medical experts may dispute questions about diagnoses and the true extent of medical injury, as well as questions about causation. A patient often has a history of illness, and there may be controversy about the causal role of the patient's pre-existing conditions. Moreover, many healthcare providers, in multiple jurisdictions, might have been involved over time in a particular patient's healthcare, and there may be controversy about allocating the liability for injury. This first point, however, is simply that healthcare-injury cases often must be decided on an individual basis, and generic rules covering categories of situations may be neither accurate nor outcome-efficient.

Second, many issues of fact in these cases must be decided with incomplete medical and scientific evidence, and the resulting uncertainty must be balanced against competing non-epistemic objectives. This is merely a particular instance of the general principle that legal factfinding always involves a balancing of the epistemic objective of law against the applicable non-epistemic objectives. ${ }^{8}$ The epistemic objective of law is to make findings of fact that are as accurate as possible, based on the limited evidence available. But there are also competing non-epistemic objectives, such as procedural fairness to parties, substantive governmental goals (e.g., an adequate supply of healthcare products and

\footnotetext{
7 Cf. Edwin Kilby, General Rapporteur, Conclusions of the European Conference "The Ever-Growing Challenge of Medical Liability: National and European Responses," held in Strasbourg, 2-3 June 2008; CONF-ML (2008) CONCL E para. 3 (Strasbourg, 3 June 2008) (stating that "in a large number of Council of Europe member states, the number of complaints and cases related to medical liability is increasing" and that " $t]$ he issues raised in such cases can be complex, but clearly it is essential that the rights of patients should be properly defended").

${ }^{8}$ Vern R. Walker, Discovering the Logic of Legal Reasoning, 35 HofstRA L. REV. 1687, 1691 (2007); Vern R. Walker, Epistemic and Non-Epistemic Aspects of the Factinding Process in Law, 3 APA NEWSL., PHIL. \& L., Fall 2003, at 132.
} 
Opinio Juris in Comparatione, Vol. 3/2009, Paper n. 1

services), and efficiency within the entire healthcare system. To the extent that the process of determining liability and compensation increases transaction costs and itself diverts resources from both healthcare and compensation, then the compensation system is inefficient. ${ }^{9}$ A legal system cannot afford to pursue accuracy at all costs, but only to the extent that is reasonable given its competing nonepistemic goals. Sometimes the appropriate balance of living with uncertainty against the cost of reducing that uncertainty can be struck generally, through rules or guidelines covering many cases, but sometimes the decision must be made case-by-case, as recognized in the preceding paragraph. And it will often be the case that compensation decisions must be made on a limited evidentiary record, with a great deal of uncertainty about the individuals involved or about information from medical science.

The third complicating factor is that, under the Commission's proposal, accurate factfinding must be ensured without creating a centralized, single factfinding institution. Institutions within the Member State of treatment must make the required case-by-case determinations, which often involve uncertainty and a balancing of competing non-epistemic objectives. Yet Community legislation would require that those "mechanisms for the compensation for harm" would be "appropriate to the nature and extent of the risk," while leaving it to Member States "to determine the nature and/or modalities of such a mechanism." ${ }^{\prime 10}$ And presumably the European Court of Justice would have to maintain a line between the minimum Community guarantees of adequacy for a compensation system, and those features left to Member State discretion.

\footnotetext{
${ }^{9}$ Cf. Kilby, supra note 7, at para. 16-18 (stating that the Conference: "took note of the extent to which barriers and obstacles to obtaining remedies could be mitigated by offering mediation, conciliation and administrative procedures as alternatives to a procedure through a court"; "considered an administrative system that is in place in some countries, characterised by availability of compensation for avoidable injuries, regardless of negligence, error or omission"; and "noted the benefits of setting up special tribunals, with the mission of resolving disputes and compensating patients for damage").
}

10 See supra note 6. 
Vern R. Walker, Designing Factfinding...

This paper therefore addresses the problem of how a central authority could ensure the provision of "safe, high-quality and efficient healthcare," and in particular ensure that patients "are guaranteed remedies and compensation when they suffer harm arising from the healthcare they receive," when determinations of compensation are made case-by-case by numerous compensation systems in multiple jurisdictions, which strike their own balances of epistemic and non-epistemic objectives. With these constraints, the problem is designing factfinding processes that are likely to produce consistent, accurate, evidence-based factfinding, and thereby contribute to high-quality healthcare by achieving outcome efficiency (neither under-compensating nor over-compensating victims) while also achieving administrative efficiency (low transaction costs).

In addressing this problem, this paper explores a framework for producing such factfinding without creating a centralized factfinding institution, and provides examples of general principles, institutional structures, and specific rules for evidence assessment. It illustrates this framework using the National Vaccine Injury Compensation Program ("VICP”) in the United States. ${ }^{11}$ Both the structure of that Program and the cases decided under it provide insights on how factfinding can be transparent, evidence-based, and coordinated, as well as (presumably) accurate, so that all potentially affected parties can be confident that the compensation system is achieving its goals. ${ }^{12}$

\footnotetext{
11 The National Vaccine Compensation Program ("VICP"), which became effective on 1 October 1988, was created by the National Childhood Vaccine Injury Act of 1986, Pub. L. No. 99-660, Title III, 100 Stat. 3755 (1986) (codified at 42 U.S.C. SS $300 \mathrm{aa}-10-300 \mathrm{aa}-34$ (2006)).

12 Undoubtedly, insights into new possibilities for accurate and efficient factfinding can also be derived from examining alternative adjudicatory systems in other countries, such as Sweden and New Zealand. See, e.g., Ulf Hellbacher, Carl Espersson \& Henry Johansson, PATIENT InJURy COMPENSATION FOR HEALTHCARE-RELATED InJuRIES (2007) (describing the Patient Injury Act in Sweden); Marie Bismark \& Ron Paterson, No-Fault Compensation in New Zealand: Harmonizing Injury Compensation, Provider Accountability, and Patient Safety, 25 HeAlth AfFAirs 278-283 (January/February 2006) (describing New Zealand's compensation system); Allen B. Kachalia, et al., Beyond negligence: Avoidability and medical injury compensation, 66 SOCIAL SCIENCE \& MEDICINE 387-402 (2008) (describing the administrative systems in both Sweden and New Zealand). The most
} 
Opinio Juris in Comparatione, Vol. 3/2009, Paper n. 1

The task of this paper is to identify the logical elements of the factfinding process, from the standpoint of achieving the epistemic objective through a decentralized but coordinated system. The objective is to survey such elements, not to discuss them in detail. Part II of this paper discusses several logical functions involved in factfinding, and the possibility of building them into distinct legal institutions. The institutional structure of the VICP provides concrete examples. Part III explores the use of legal rules as coordinating mechanisms in factfinding, with particular attention to the types of rules that can govern the process of evidence assessment.

\section{Logical Functions and Institutional Structures}

The Vaccine Injury Compensation Program is a hybrid administrative-judicial system for providing compensation to persons who have sustained vaccine-related injuries. Compensation awards for the VICP are paid out of the Vaccine Injury Compensation Trust Fund, which is funded in turn by an excise tax on each dose of covered vaccine. ${ }^{13}$ For a number of reasons, the VICP is a good source of insights and examples for coordinating compensation factfinding for cross-border healthcare. First, the contested cases involve complex issues of fact, which can be decided accurately only on a case-by-case basis, taking into account medical, scientific, and other expert evidence along with non-expert evidence. Second, the VICP explicitly balances the epistemic objective of accurate, evidence-based factfinding with several non-epistemic objectives, including ensuring an adequate supply of vaccines and stabilizing

desirable targets of study are systems of adjudication that have been in operation long enough to provide data on feasibility, efficiency and reasoning in support of outcomes.

13 The Vaccine Injury Compensation Trust Fund is established under 26 U.S.C. $\int 9510$ (2006), and payment of compensation from that Fund is authorized by 42 U.S.C. $\int 300 a a-15(i)(2)$ (2006). Also see United States Department of Health and Human Services, Health Resources and Services Administration, Vaccine Injury Compensation Trust Fund, http://www.hrsa.gov/vaccinecompensation/VIC Trust Fund.htm . 
Vern R. Walker, Designing Factfinding...

vaccine costs. ${ }^{14}$ A goal of the VICP is to provide an efficient compensation system, utilizing a no-fault alternative to traditional tort litigation..$^{15}$

Third, both the system of legal rules that governs the factfinding and the evidence assessment conducted in particular cases are transparent and documented. Petitions claiming compensation from the Trust Fund are filed in the United States Court of Federal Claims, and name the Secretary of the United States Department of Health and Human Services as the respondent. ${ }^{16}$ Petitions that are contested by the Secretary are to be decided, in the first instance and reasonably quickly, by one of eight special masters in the Office of Special Masters, which Congress established for this purpose within the Court of Federal Claims. ${ }^{17}$ In keeping with the efficiency goals of the VICP, special masters have the

14 See United States Department of Health and Human Services, Health Resources and Services Administration, Home Page for the VICP, http://www.hrsa.gov/vaccinecompensation/. The Department states:

The VICP was established to ensure an adequate supply of vaccines, stabilize vaccine costs, and establish and maintain an accessible and efficient forum for individuals found to be injured by certain vaccines. The VICP is a no-fault alternative to the traditional tort system for resolving vaccine injury claims that provides compensation to people found to be injured by certain vaccines.

Id.

15 United States Department of Health and Human Services, Health Resources and Services Administration, April 2006 Strategic Plan for the VICP, http://www.hrsa.gov/vaccinecompensation/-strategic_plan.htm. The Strategic Plan contains the Mission Statement of the VICP:

To process National Vaccine Injury Compensation Program (VICP) claims expeditiously and fairly utilizing current vaccine safety research to determine injuries thought to be caused by vaccines, and raise awareness about the existence of the VICP.

Id. It states the Vision of the VICP as:

To fairly compensate individuals injured by covered vaccines quickly, easily and with certainty, and create an environment that fosters the production and use of existing vaccines, and the development of new, safe and effective vaccines.

Id. The legislative history of the statute states as a VICP goal the establishment of "a Federal 'no-fault' compensation program under which awards can be made to vaccine-injured persons quickly, easily, and with certainty and generosity." H.R. REP. 99-908, 1986 U.S.C.C.A.N. 6344 (September 26, 1986).

1642 U.S.C. \300aa-12(a), (b)(1) (2006).

1742 U.S.C. $\int 300 \mathrm{aa}-12(\mathrm{c})$, (d) (2006), which directs that: 
Opinio Juris in Comparatione, Vol. 3/2009, Paper n. 1

flexibility to conduct proceedings that are efficient and somewhat tailored to the needs of each petition. ${ }^{18}$ A special master's decision on a petition must include "findings of fact and conclusions of law." ${ }^{19}$ As will be discussed in more detail infra, under certain conditions and subject to certain constraints, the Court of Federal Claims has jurisdiction to review a special master's decision, and a judgment of that Court can be appealed to the United States Court of Appeals for the Federal Circuit. ${ }^{20}$

A special master to whom a petition has been assigned shall issue a decision on such petition with respect to whether compensation is to be provided under the Program and the amount of such compensation. The decision of the special master shall--

(i) include findings of fact and conclusions of law, and

(ii) be issued as expeditiously as practicable but not later than 240 days, exclusive of suspended time under subparagraph (C), after the date the petition was filed.

Id. at $\ 300$ aa-12(d)(3)(A). The same statutory section, at sub-section (d)(3)(C), provides that

a special master shall suspend the proceedings one time for 30 days on the motion of either party. After a motion for suspension is granted, further motions for suspension by either party may be granted by the special master, if the special master determines the suspension is reasonable and necessary, for an aggregate period not to exceed 150 days.

Id. at $₫ 300 \mathrm{aa}-12(\mathrm{~d})(3)(\mathrm{C})$.

18 See, e.g., 42 U.S.C. \$ 300aa-12(d). The Court of Federal Claims, taking into account the recommendations of the special masters, is authorized to promulgate Vaccine Rules that shall:

(A) provide for a less-adversarial, expeditious, and informal proceeding for the resolution of petitions,

(B) include flexible and informal standards of admissibility of evidence,

(C) include the opportunity for summary judgment,

(D) include the opportunity for parties to submit arguments and evidence on the record without requiring routine use of oral presentations, cross examinations, or hearings, and

(E) provide for limitations on discovery and allow the special masters to replace the usual rules of discovery in civil actions in the United States Court of Federal Claims.

42 U.S.C. $\$ 300 a a-12(d)(2)$ (2006). The Vaccine Rules of the United States Court of Federal Claims are available at: http://www.uscfc.uscourts.gov/.

19 See supra note 17.

2042 U.S.C. \300aa-12(e), (f) (2006). 
Vern R. Walker, Designing Factfinding...

Thus, the VICP provides a robust example of one attempt to construct an efficient compensation system for claims of injury from healthcare. ${ }^{21}$ The task of this part of the paper is to identify the major logical functions within a process of factfinding that might be allocated to separate governmental institutions. In some circumstances, it might be more efficient to combine some of these functions into a single institution. But examining a program such as the VICP, where the functions are often separated, helps clarify what the distinct functions are, and suggests what the major advantages and disadvantages might be of separating or integrating those functions.

\section{A. Adjudication in the First Instance}

Factfinding is a process that involves, at a minimum, three tasks: receiving evidence and creating an evidentiary record, assessing the probative value of the evidence in the record, and using that evidence to make the findings of fact that determine the applicability of legal rules. In the VICP, the special master designated to decide a particular petition performs these tasks in the first instance. ${ }^{22}$ This section provides a brief overview of these three tasks, taking a logical rather than a procedural approach.

At the outset, statutes and regulations, as well as case law interpreting the statutes and regulations, generally provide the substantive legal rules governing the adjudication. The substantive legal rules state the conditions under which governmental action is or is not justified. In the case of the

\footnotetext{
${ }^{21}$ The major feature that might appear to make the VICP less useful for addressing the problem posed in this paper is that it is a somewhat centralized factfinding structure. However, this is not a major concern because the VICP still has substantial problems with achieving consistent, accurate, evidence-based factfinding, and employs a number of mechanisms to oversee factfinding outcomes.

22 The chief special master, whose position and responsibilities are established by the statute, designates a special master to adjudicate a petition that has been filed. 42 U.S.C. \$300aa-12(c), (d) (2006).
} 
Opinio Juris in Comparatione, Vol. 3/2009, Paper n. 1

VICP, for example, the statute provides that a special master shall award compensation to a petitioner if the special master makes certain findings "on the record as a whole" - findings such as whether the person who is the subject of the petition received a vaccine that is covered under the VICP. ${ }^{23} \mathrm{~A}$ major factual issue in contested petitions is often causation: whether the vaccine caused the injury alleged. The statute provides two ways for a petitioner to establish causation. ${ }^{24}$ The first is a statutory presumption of causation, which is triggered when the person sustained an injury listed for that vaccine in the Vaccine Injury Table, within the time period after vaccination specified in that Table. ${ }^{25}$ If the petitioner demonstrates that these conditions are satisfied, then the statute directs that the vaccine is (rebuttably) presumed to be a cause of the injury. The second way of proving causation applies if the injury complained of is not listed in the Vaccine Injury Table, or the onset occurred outside the time period

2342 U.S.C. $\int 300 a a-13(A)(1)$ (2006) provides:

Compensation shall be awarded under the Program to a petitioner if the special master or court finds on the record as a whole--

(A) that the petitioner has demonstrated by a preponderance of the evidence the matters required in the petition by section $300 \mathrm{aa}-11(\mathrm{c})(1)$ of this title, and

(B) that there is not a preponderance of the evidence that the illness, disability, injury, condition, or death described in the petition is due to factors unrelated to the administration of the vaccine described in the petition.

42 U.S.C. $\int 300 a a-11(c)(1)$, in turn, specifies a list of issues to be proved, such as whether the person who is the subject of the petition (that is, the person who allegedly suffered injury or died due to the vaccine) "received a vaccine set forth in the Vaccine Injury Table or, if such person did not receive such a vaccine, contracted polio, directly or indirectly, from another person who received an oral polio vaccine." Id. at (c)(1)(A).

${ }^{24}$ Althen v. Secretary of Health and Human Services, 418 F.3d 1274, 1278 (Fed.Cir. 2005) (describing the two ways as "a statutorily-prescribed presumption of causation" in the case of a "Table injury," and "causation in fact" in the case of an "off-Table injury").

2542 U.S.C. \300aa-11(c)(1)(C)(i) (2006). The Vaccine Injury Table is an administratively maintained table of covered vaccines, injuries recognized as related to particular vaccines, and recognized time periods for the onset of those injuries. 
Vern R. Walker, Designing Factinding...

listed in that Table. ${ }^{26}$ In the Althen case in 2005, the Federal Circuit articulated the rule that a petitioner attempting to prove causation this second way must prove

that the vaccination brought about her injury by providing: (1) a medical theory causally connecting the vaccination and the injury; (2) a logical sequence of cause and effect showing that the vaccination was the reason for the injury; and (3) a showing of a proximate temporal relationship between vaccination and injury. ${ }^{27}$

Thus, the substantive legal rules (whether adopted by statute, regulation, or case law) identify the issues to be proved. Indeed, taken as an organized whole, those rules identify all of the issues of fact that might be relevant within the factfinding process. The factfinder generally has no authority to make findings on issues not relevant to the proceeding.

Although the substantive legal rules establish the factual issues to be decided, in the context of a particular adjudication, a presiding official must identify what those rules are and then create the evidentiary record that will form the basis of the findings. An evidentiary record is essential under the rule of law, so that the basis of the decision will be transparent, and potentially affected parties will be able to ascertain for themselves whether the factfinding process is legitimate. In petition adjudications under the VICP, the special master is both the presiding official who creates the evidentiary record and the factfinder who assesses the probative value of the evidence in that record. In other institutions, these two functions are sometimes separated, as where a judge is the presiding official and a jury is the factfinder. There are also differences among institutions about who has the power or the responsibility to actually produce the evidence that is to be entered into the record. In some institutions, an

\footnotetext{
2642 U.S.C. \300aa-11(c)(1)(C)(ii) (2006).

${ }^{27}$ Althen, supra note 24, 418 F.3d at 1278.
} 
investigating judge or other officer is empowered to generate the evidence (e.g., discover documents, appoint experts, and question witnesses). In the VICP, the parties produce the evidence and submit it to the special master for inclusion into the record. On the issue of causation, for example, such evidence often includes: the fact testimony of lay witnesses about the nature and onset of symptoms, medical records containing the notes of treating physicians and other healthcare providers, results of medical tests, letters and other statements by treating physicians, and opinions by experts retained either by the petitioner or by the government. The special master has wide discretion to fashion the procedures for creating the evidentiary record - e.g., to decide whether a hearing is needed to take the oral testimony of witnesses. ${ }^{28}$

Finally, after the applicable rules and issues to be proved have been identified and the evidentiary record has been created, the factfinder must review that evidence, assess its probative value with respect to each issue, and reason from the evidence to make the factual findings in the case. In the VICP cases, the special master has a fairly short period of time in which to create the record, assess the

2842 U.S.C. \300aa-12(d)(3)(B) (2006) provides:

In conducting a proceeding on a petition a special master-

(i) may require such evidence as may be reasonable and necessary,

(ii) may require the submission of such information as may be reasonable and necessary,

(iii) may require the testimony of any person and the production of any documents as may be reasonable and necessary,

(iv) shall afford all interested persons an opportunity to submit relevant written information-

(I) relating to the existence of the evidence described in section 300aa-13(a)(1)(B) of this title, or

(II) relating to any allegation in a petition with respect to the matters described in section 300aa-11(c)(1)(C)(ii) of this title, and

(v) may conduct such hearings as may be reasonable and necessary.

There may be no discovery in a proceeding on a petition other than the discovery required by the special master. 
Vern R. Walker, Designing Factfinding...

evidence in the record, and issue a decision. ${ }^{29}$ The decision of the special master must state whether the petitioner is entitled to compensation under the VICP and the amount of any such compensation, and must include "findings of fact and conclusions of law."

\section{B. Separate Factfinding on Discrete Issues: Omnibus and Other Specialized}

\section{Proceedings}

At the level of adjudication in the first instance, it is sometimes efficient to create separate factfinding processes for discrete issues that arise within petitions. This section discusses two examples: generic issues of fact common to multiple cases and discrete issues of fact within a single case.

Fairly early in the history of the VICP, it became clear that, while every petition includes issues of fact peculiar to the particular case, many petitions could have a single issue of fact in common. An example of such a common issue is what is call "general causation." General causation is the issue of whether a type of vaccine can cause a particular type of injury at all. It is a generic question common to all petitions that involve both the same type of vaccine and the same type of alleged injury. Moreover, a finding of general causation would be based on an assessment of the state of the art of medical science in general, and not on the particular facts of any individual case. (The evidence specific to the particular case would come into play in deciding "specific causation" - that is, whether the particular vaccination in fact caused the particular injury. A special master might not find specific causation in the petitioner's favor, even if the vaccine involved can cause such an injury in some circumstances.)

\footnotetext{
29 See supra note 17.

3042 U.S.C. \ 300aa-12(d)(3)(A) (2006).
} 
Opinio Juris in Comparatione, Vol. 3/2009, Paper n. 1

It becomes efficient, therefore, if there are enough petitions having the same common question, to decide that common question either in a separate proceeding or in a lead or test case. In the VICP, special masters have conducted "omnibus proceedings" focused on common issues in at least four instances: the "rubella arthropathy" cases, the "polio-myelitis" cases, the "tuberous sclerosis" cases, and the "thimerosal/autism" cases. ${ }^{31}$

A second example of separating factfinding processes occurs within a single case. It may happen that it is more efficient to adjudicate some particular issues before adjudicating others. For example, in Keenan, the special master first took evidence, conducted a hearing, and issued findings of fact related to the onset of the petitioner's alleged injuries after receiving a Hepatitis B vaccine, "for the purpose of determining the facts upon which the Court and the experts may rely in rendering a decision on entitlement." ${ }^{32}$ Over a year later, in the same proceeding, the special master conducted a second hearing, on the issue of causation. ${ }^{33}$

\section{Deciding Generic Issues through Administrative Rulemaking}

Another technique for deciding an issue common to many cases is to remove factfinding on that issue from the first-instance adjudicator altogether, and to confer factfinding authority on an administrative agency with rulemaking powers. The administrative agency can use rulemaking procedures to create an evidentiary record and to issue binding rules that decide the treatment of the common issue in all particular cases. The new regulation might achieve coordination through a

\footnotetext{
${ }^{31}$ Berry v. Secretary of Health and Human Services, 2006 U.S. Claims LEXIS 285, at*31 (Sep. 13, 2006).

32 Keenan v. Secretary of Health and Human Services, 2007 U.S. Claims LEXIS 121, at*6-*8 (Apr. 5, 2007).

${ }^{33} I d$.
} 
Vern R. Walker, Designing Factfinding...

combination of new substantive rules, regulatory presumptions, or some other procedural devices. Due process concerns are addressed insofar as all potentially affected parties have a right to participate in the rulemaking proceedings.

Deciding a common issue generically through administrative rulemaking can have clear efficiencies. First, the administrative proceeding itself might be an "informal" type of notice-andcomment rulemaking, which may be more efficient than an adjudication. Second, the outcome is a rule binding on and in all adjudications, with the result that the adjudicative proceedings are more efficient if the substantive administrative rules cannot be re-litigated.

In addition, deciding a factual, generic issue administratively can lead to more accurate outcomes. Assuming that the issue itself is appropriate for generic determination, an administrative factfinding process would allow a full range of public participation from diverse interest groups, as well as expert participation by medical and scientific individuals, groups or institutions. Thus, the evidentiary record is likely to be more complete, and the outcome is likely to take into account more relevant evidence.

The VICP utilizes this administrative approach to a limited but important extent, through the administrative authority of the Secretary of the Department of Health and Human Services to revise the Vaccine Injury Table. ${ }^{34}$ For example, in 1995 and 1997 the Secretary used this authority to amend the Table. $^{35}$

3442 U.S.C. \300aa-14(c) provides:

(1) The Secretary may promulgate regulations to modify in accordance with paragraph (3) the Vaccine Injury Table. In promulgating such regulations, the Secretary shall provide for notice and opportunity for a public hearing and at least 180 days of public comment. 
Opinio Juris in Comparatione, Vol. 3/2009, Paper n. 1

\section{Record-Making through Advisory Committees}

Advisory committees can be used to enhance the accuracy and efficiency of factfinding in several ways. First, an advisory committee might be formally inserted into the rulemaking or the adjudication procedures and function simply in an ancillary advisory capacity. Second, an advisory committee might be given its own independent authority to pose or respond to factual questions, to assemble evidence into a record, and to issue its own findings. Such an institution might develop influence through its judicious use of its own expertise within its own sphere of knowledge.

The VICP provides several examples. First, the statute establishes the Advisory Commission on Childhood Vaccines, which plays a formal role in rulemaking to revise the Vaccine Injury Table. The Advisory Commission consists of nine members appointed by the Secretary (and must include representatives of the general public), as well as three non-voting ex officio members from governmental agencies. ${ }^{36}$ The functions of the Advisory Commission include recommending changes in the Vaccine

(3) A modification of the Vaccine Injury Table under paragraph (1) may add to, or delete from, the list of injuries, disabilities, illnesses, conditions, and deaths for which compensation may be provided or may change the time periods for the first symptom or manifestation of the onset or the significant aggravation of any such injury, disability, illness, condition, or death.

35 Department of Health and Human Services, National Vaccine Injury Compensation Program Revision of the Vaccine Injury Table, 60 Fed.Reg. 7678 (Feb. 8, 1995) (final rule); Department of Health and Human Services, National Vaccine Injury Compensation Program: Revisions and Additions to the Vaccine Injury Table--II, 62 Fed.Reg. 7685 (Feb. 20, 1997) (final rule).

3642 U.S.C. $\$ 300 a a-19$ (a) (2006) provides:

The Commission shall be composed of:

(1) Nine members appointed by the Secretary as follows:

(A) Three members who are health professionals, who are not employees of the United States, and who have expertise in the health care of children, the epidemiology, etiology, and prevention of childhood diseases, and the adverse reactions associated with vaccines, of whom at least two shall be pediatricians.

(B) Three members from the general public, of whom at least two shall be legal representatives of children who have suffered a vaccine-related injury or death. 
Vern R. Walker, Designing Factfinding...

Injury Table, either "on its own initiative or as the result of the filing of a petition." ${ }^{37}$ Any person may petition the Secretary to propose regulations to amend the Table, and any petition that is not clearly frivolous must be referred to the Advisory Commission for its recommendations. ${ }^{38}$ The Secretary may not propose a regulation to modify the Table unless the Secretary has first provided the Advisory Commission an opportunity to provide recommendations and comments. ${ }^{39}$ This opportunity is in effect a chance for the Advisory Commission to submit evidence for the administrative record, including evidence in the form of its own findings and recommendations, which the Secretary could ignore in the rulemaking only at the risk of being held by a court to be "arbitrary and capricious."

Second, the Institute of Medicine, a branch of the National Academy of Sciences, issued in 1994 an influential report entitled Adverse Events Associated with Childhood Vaccines: Evidence Bearing on Causality, on which special masters frequently rely "as a sound source for answering difficult issues of medical plausibility and causation." ${ }^{, 1}$

(C) Three members who are attorneys, of whom at least one shall be an attorney whose specialty includes representation of persons who have suffered a vaccine-related injury or death and of whom one shall be an attorney whose specialty includes representation of vaccine manufacturers.

(2) The Director of the National Institutes of Health, the Assistant Secretary for Health, the Director of the Centers for Disease Control and Prevention, and the Commissioner of Food and Drugs (or the designees of such officials), each of whom shall be a nonvoting ex officio member.

3742 U.S.C. \300aa-19(f) (2006).

3842 U.S.C. $\int 300 \mathrm{aa}-14(\mathrm{c})(2)(2006)$.

3942 U.S.C. $\$ 300 \mathrm{aa}-14(\mathrm{~d})$ (2006).

40 See Administrative Procedure Act, codified at 5 U.S.C. $\int 706(2)(A)(2006)$.

${ }^{41}$ Kelley v. Secretary of Health and Human Services, 68 Fed.Cl. 84, 91 note 11 (Ct.Fed.Cl. 2005) (quoting Althen v. Secretary of Health and Human Services, 2003 WL 21439669, at*11 note 28 (2003)). 
Opinio Juris in Comparatione, Vol. 3/2009, Paper n. 1

\section{E. Judicial Review of Issues of Fact and Law}

Judicial review is generally accepted as an essential feature of legal factfinding, yet there are a variety of options on the structures and rules for such review. Judicial review in the VICP is an interesting hybrid of American law, drawing upon traditional appellate review of court decisions, as well as on judicial review of administrative decisions. Therefore the VICP illustrates a large number of options.

First, after a special master has issued a decision on a petition for compensation, either the petitioner or the Secretary may file a motion with the United States Court of Federal Claims to have the court review the decision. ${ }^{42}$ That court then has jurisdiction to expeditiously review the record created by the special master and has the power to sustain the special master's decision or to set it aside, and in the latter case it may either issue its own findings of fact and conclusions of law, or remand the petition for further action by the special master. ${ }^{43}$ In order to set aside "any findings of fact or conclusion of law" of the special master, the court must find them to be "arbitrary, capricious, an abuse of discretion,

4242 U.S.C. \300aa-12(e)(1) (2006).

43 The statute provides:

... the United States Court of Federal Claims shall have jurisdiction to undertake a review of the record of the proceedings and may thereafter-

(A) uphold the findings of fact and conclusions of law of the special master and sustain the special master's decision,

(B) set aside any findings of fact or conclusion of law of the special master found to be arbitrary, capricious, an abuse of discretion, or otherwise not in accordance with law and issue its own findings of fact and conclusions of law, or

(C) remand the petition to the special master for further action in accordance with the court's direction.

The court shall complete its action on a petition within 120 days of the filing of a response under paragraph (1) excluding any days the petition is before a special master as a result of a remand under subparagraph (C). The court may allow not more than 90 days for remands under subparagraph (C).

42 U.S.C. $\int 300 a a-12(e)(2)(2006)$. 
Vern R. Walker, Designing Factfinding...

or otherwise not in accordance with law." ${ }^{44}$ This standard of review is the traditional standard governing judicial review of a final action by an administrative agency. ${ }^{45}$ In the context of the VICP, this has been interpreted as applying different standards of review to three types of determination that a special master might make: a finding on an issue of fact, a discretionary decision with respect to the process of adjudication, and a conclusion of law. As the Court of Federal Claims stated in Zatuchni:

Thus, the Special Master's decision may be set aside only if the findings of fact are arbitrary and capricious, the legal conclusions are not in accordance with law, or the discretionary rulings constitute an abuse of discretion. ${ }^{46}$

Normally, the review of the special master's decision in the Court of Federal Claims is ordinarily conducted by a single judge of that court. ${ }^{47}$

A judgment of the Court of Federal Claims on a reviewed petition is itself subject to review by the United States Court of Appeals for the Federal Circuit. ${ }^{48}$ In such an appeal, a distinction is made between a judgment of the Court of Federal Claims that sustains or merely sets aside the special master's decision, and a judgment that makes its own findings and conclusions. With regard to questions of law, this distinction makes no difference, because the Federal Circuit reviews such questions de novo, and owes no deference to the Court of Federal Claims. ${ }^{49}$ With regard to findings of

${ }^{44}$ Id.; see Althen, supra note 24, F.3d at 1277.

45 See Administrative Procedure Act, codified at 5 U.S.C. $\int 706(2)(A)$ (2006).

${ }^{46}$ Zatuchni v. Secretary of Health and Human Services, 69 Fed.Cl. 612, 620 (Ct.Fed.Cl. 2006).

47 See Vaccine Rule 26 of the United States Court of Federal Claims.

4842 U.S.C. \300aa-12(f) (2006).

49 Althen, supra note 24, 418 F.3d at 1277-78; De Bazan v. Secretary of Health and Human Services, 539 F.3d 1347, 135051 (Fed.Cir. 2008). 
Opinio Juris in Comparatione, Vol. 3/2009, Paper n. 1 fact, however, the distinction does come into play. In the former case, when the Federal Circuit reviews a judgment of the Court of Federal Claims that upholds or sets aside a special master's findings of fact, the Federal Circuit reviews the special master's findings under the same "arbitrary and capricious standard" as the Court of Federal Claims uses. ${ }^{50}$ In the latter case, "when the Court of Federal Claims makes its own factual findings either in the first instance or when it has found the special master's findings arbitrary and capricious," the Federal Circuit reviews the findings of the Court of Federal Claims for "clear error." 51 This complication results from the fact that the statute grafts the "arbitrary and capricious" standard of administrative judicial review into a judicial appellate system.

The VICP's two-layered system of judicial review, together with Congress's introduction of the standards for judicial review of administrative findings, serves to focus attention on three logically distinct types of determination, and on options for judicial review in each case. First, and of primary concern given the focus of this paper, are findings of fact. Adapting one formulation of the United States Supreme Court from its administrative setting, a factfinder's decision would be arbitrary and capricious if the factfinder

relied on factors which Congress has not intended [the factfinder] to consider, entirely failed to consider an important aspect of the problem, offered an explanation for [the] decision that runs counter to the evidence before [the factfinder], or is so implausible

\footnotetext{
50 De Bazan, supra note 49, 539 F.3d at 1350-51.

${ }^{51}$ Id., 539 F.3d at 1351.
} 
Vern R. Walker, Designing Factfinding...

that it could not be ascribed to a difference in view or the product of [the factfinder's] expertise. $^{52}$

Put in other terms, the factfinder is acting in an arbitrary and capricious manner, and a finding of fact is unwarranted, if (1) the finding is based on irrelevant evidence or on evidence not in the record, or (2) the finding fails to take into account relevant evidence in the record or the fact that relevant evidence is missing from the record, or (3) the reasoning that connects the evidence to the finding is missing altogether or fails to provide a rational explanation. If the reviewing court finds that the factfinder's finding is arbitrary and capricious, then it may be efficient for that court to make its own findings of fact if the evidentiary record is adequate, rather than always remanding the case to the first-instance factfinder. (This is the situation between the Court of Federal Claims and the special masters.) In some instances, however, only the first-instance factfinder is in a position to make an accurate determination - for example, where the finding rests critically upon an evaluation of the credibility of a witness's oral testimony.

The second logical type of determination is a ruling on procedures. Such a ruling should take into account both the particular circumstances and such legal principles as due process, and it makes sense that a court would review such a ruling on the deferential "abuse of discretion" standard. This standard of review may not be quite as deferential as the "arbitrary and capricious" standard, however, because reviewing courts, when compared to first-instance presiding officials, are often in as good a position, or even a better position, to make this type of ruling.

\footnotetext{
52 See Hines v. Secretary of Health and Human Resources, 940 F.2d 1518, 1527 (Fed.Cir. 1991) (quoting Motor Vehicle Mfrs. Ass'n v. State Farm Mut. Auto. Ins. Co., 463 U.S. 29, 43 (1983), discussing the arbitrary and capricious standard of review for agency rulemaking under the Administrative Procedure Act).
} 
Opinio Juris in Comparatione, Vol. 3/2009, Paper n. 1

The third logical type of determination is a statement of the legal rules that are applicable to the proceeding, and reviewing courts should review such conclusions de novo and without deference to the lower tribunal. Stating what the legal rules are and interpreting their meaning is the peculiar province of appellate institutions, whose task it is to ensure that a complete and consistent body of law is interpreted uniformly in a multitude of particular cases.

\section{Using Legal Rules as Coordinating Tools for Factfinding}

Given the task of designing factfinding systems that will ensure accurate, evidence-based factfinding throughout decentralized but coordinated compensation systems, the previous part of this paper identified several logical tasks in the factfinding process and discussed possible allocations of those logical functions to legal institutions, with particular reference to the institutional structure of the VICP. Part III examines the use of legal rules as coordinating mechanisms in factfinding, with particular attention to the types of rules that can govern the process of evidence assessment. After a brief discussion of the logical types of legal rules, this part of the paper illustrates a number of evidence-assessment rules through examples from the VICP.

\section{A. The Types and Roles of Legal Rules}

From the perspective of a logical analysis of factfinding, legal rules are conditional propositions that have been authoritatively adopted as universally applicable. ${ }^{53} \mathrm{~A}$ conditional proposition has the

53 This part discusses legal rules from a basic logical perspective, utilizing only propositional logic. This basic formulation, however, can be embedded in more robust logical frameworks for modeling evidentiary reasoning, such as predicate logics or defeasible logics. For examples of general frameworks applied particularly to the legal domain, see Kevin D. Ashley \& Edwina L. Rissland, Law, learning and representation, 150 ARTIFICIAL INTELLIGENCE 17 (2003); TERENCE Anderson, David Schum \& William Twining, Analysis of Evidence (2d Ed. 2005); L. Karl Branting, ReAsoning With Rules and PReCedents: A Computational Model of Legal Analysis (2000); Joseph B. KadANE \& David A. Schum, A Probabilistic Analysis of the Sacco and VanzetTi Evidence (1996); JaAp Hage, Studies 
Vern R. Walker, Designing Factfinding...

logical form "if $p$, then $q$," where $p$ and $q$ stand for two constituent propositions. A rule is a statement that finding proposition $p$ (the condition) to be true warrants finding $q$ (the conclusion) to be true also. Legal rules are authoritatively adopted by institutions empowered to adopt them, using lawful procedures appropriate to those institutions and circumstances. Such rules are intended to be universally binding in their application - that is, they must apply in all situations described by the condition in the "if" clause. If there are to be any exceptions to the rule, other rules should be adopted that identify those exceptions and govern the reasoning in those exceptional cases. A complete system of legal rules, therefore, would identify all of the legally recognized conditions or bases for reaching the conclusion stated in the rule.

For purposes of the analysis in this paper, rules are usefully divided into two broad categories. First, "substantive legal rules" identify the factual conditions under which some particular type of governmental action or inaction is justified. One function of substantive rules is to formulate, for any particular course of governmental conduct, a complete set of factual conditions that make that conduct lawful. From the perspective of factfinding, the substantive legal rules provide a complete list of the substantive issues of fact that are relevant in the factfinding proceeding.

The second category of rules consists of "process legal rules" - rules that govern the factfinding process itself, as well as the process of adopting, modifying, or interpreting the substantive legal rules. ${ }^{54}$

in Legal Logic (2005); Henry Prakken, Logical Tools for Modelling Legal Argument (1997); Edwina L. Rissland, Kevin D. Ashley \& R.P. Loui, AI and Law: A fruitful synergy, 150 ARTIFICIAL InTELLIGENCE 1 (2003); DAVID A. Schum, Evidential Foundations of Probabilistic Reasoning (1994); Bart Verheij, Virtual Arguments: On the Design of Argument Assistants for Lawyers and Other Arguers (2005); Vern R. Walker, A Default-Logic Paradigm for Legal Fact-Finding, 47 Jurimetrics 193 (2007); Douglas WALTON, LEGAL ARgumentATION AND EvidenCE (2002).

\footnotetext{
54 Walker, supra note 53, at 232-41.
} 
Whereas substantive legal rules determine the content of the factfinding process, process legal rules govern the conduct of the factfinding process. One might say that whereas substantive legal rules govern the factfinding process "from the inside," process rules govern it "from the outside." Both types of rules, therefore, are important mechanisms in coordinating a multitude of factfinding processes.

Substantive legal rules can be established legislatively (statutes), administratively (regulations), and judicially (court decisions). For example, in the VICP, the statute establishes certain conditions for a lawful award of compensation; administrative rulemaking can revise the Vaccine Injury Table and therefore modify the conditions triggering the statutory presumption of causation in cases involving Table injuries; and Federal Circuit judicial decisions can interpret those conditions by making them more precise. Figure 1 shows a simplified logic diagram of selected high-level legal rules related to proving causation in adjudications under the VICP. In this "inverted tree" diagram, the ultimate conclusion to be decided is the top node - namely, whether "the petitioner is entitled to compensation under the National Vaccine Injury Compensation Program." In the proceeding on the petition, the petitioner is attempting to prove this conclusion true (which would require the Trust Fund to take action to provide the compensation), while the Secretary might contest this outcome by proving the conclusion false, or at least keeping it undecided. As the logic diagram indicates, this ultimate conclusion is true if, but only if, the two propositions on the second-level are true: "all procedural requirements are satisfied" and "all substantive requirements are satisfied." These two conditions are connected to the ultimate conclusion by the conjunctive connective "AND." The statute also provides what is in effect an affirmative defense: if "the injury or death is due to factors unrelated to the vaccination," then the petitioner is not entitled to compensation. ${ }^{55}$ This proposition, if it proves to be

\footnotetext{
55 Althen, supra note 24, 418 F.3d at 1278 (placing the burden of proving this defeater proposition on the government in petition proceedings under the VICP).
} 
Vern R. Walker, Designing Factfinding...

true, defeats an otherwise successful prima facie case, and this is shown in the diagram in Figure 1 by its being connected to the ultimate conclusion by the logical connective "UNLESS." 
Vern R. Walker, Designing Factfinding...

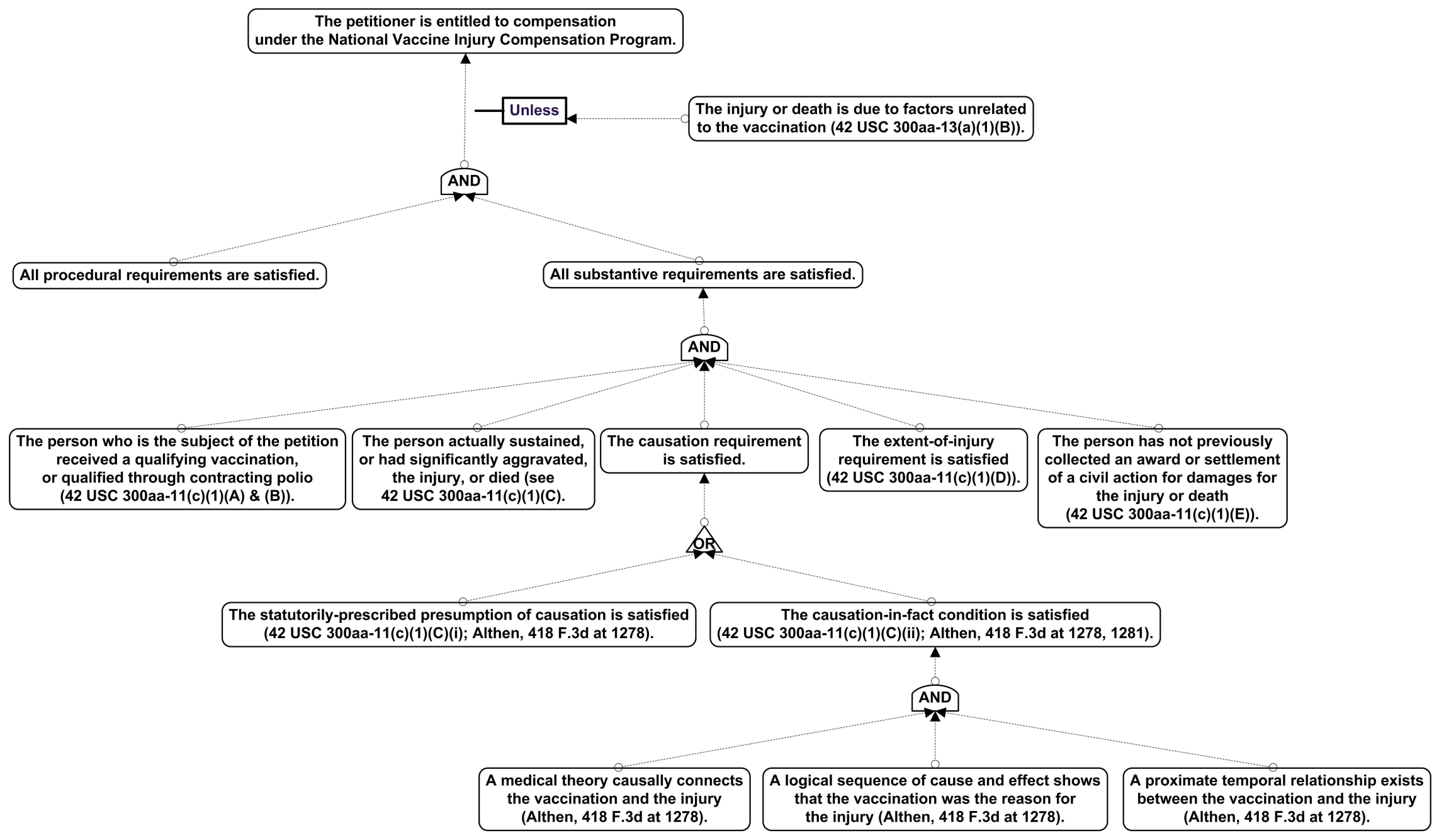

Figure 1. Simplified Logic Diagram Illustrating Selected High-Level Substantive Legal Rules for the National Vaccine Injury Compensation Program 
With regard to substantive requirements, the statute establishes five elements to be proved shown in Figure 1 on the third level of the tree. The statute also provides that the third of these conditions, the causation requirement (shown as the center condition on the third level of the diagram), can be satisfied in either of two ways: either when "the statutorily-prescribed presumption of causation is satisfied" (in Table-injury cases) or when "the causation-in-fact condition is satisfied" (in "off-Table" cases). In the logic diagram in Figure 1, these alternative lines of proof on the fourth level are connected to the causation-in-fact conclusion by the disjunctive "OR."

Finally, in the case of these off-Table injuries, the Court of Appeals for the Federal Circuit added the rule in 2005 that the causation-in-fact condition can be satisfied by the petitioner's

providing: (1) a medical theory causally connecting the vaccination and the injury; (2) a

logical sequence of cause and effect showing that the vaccination was the reason for the

injury; and (3) a showing of a proximate temporal relationship between vaccination and injury. ${ }^{56}$

This conjunction of three conditions is depicted on the last level shown in Figure 1.

Figure 1 illustrates how substantive legal rules determine the content of the findings of fact required in order for governmental action to be lawful. Factfinding is the process of assembling evidence relevant to making those findings, evaluating the probative value of that evidence, and deciding which of the propositions at the ends of the branches of a rule tree (such as the one in Figure 1) are true. ${ }^{57}$

\footnotetext{
${ }^{56} I d ., 418$ F.3d at 1278.

${ }^{57}$ As stated earlier in the text, the diagram in Figure 1 shows the simplified logic of selected high-level rules - that is, the propositional connectives among the fundamental conditions for entitlement to compensation under the VICP. This paper suggests how new statutory amendments, administrative regulations, and judicial interpretations might extend or modify such a rule system. The paper does not intend to suggest, however, that the content of legal rules can be completely formalized, or that the interaction between logical form and semantic meaning is straightforward. While a long-term goal
} 
Opinio Juris in Comparatione, Vol. 3/2009, Paper n. 1

Process legal rules do not define the issues of fact in the same way that substantive rules do. Process rules play a variety of roles ancillary to the main factfinding task. Some process rules are strictly procedural, and state the conditions for decisions of presiding officials in controlling the legal proceedings. For example, in a case before a special master under the VICP, Vaccine Rule 20 prescribes the necessary conditions for written motions: "A motion, unless made orally, shall be made in writing, shall state with particularity the grounds therefore, shall set forth the relief or order sought, and shall be filed with the clerk." ${ }^{58}$ The conditions established by such procedural rules can also be modeled using inverted rule trees, similar to the one shown in Figure 1. In this example, however, the ultimate conclusion at the top of the tree is not the ultimate issue of compensation, but rather the issue of whether the motion has been validly made. Of course, a process ruling may well have substantial impact on the outcome of a case, as where an invalid motion fails to preserve an objection for appeal. Thus, substantive legal rules and process legal rules play different critical roles in legal decision-making.

The focus of the next section of this paper, however, will be upon a different type of process legal rule - what may be called "evidentiary process rules," "evidence-assessment rules," or simply "evidentiary rules." Certain process rules govern the process of evidence assessment directly, and therefore the process of factfinding directly. Such evidentiary process rules are binding on the various participants in the factfinding process, and govern various aspects of how they conduct that process. For example, some evidentiary rules might determine what types of evidence can and cannot be

may be to increase the extent of formal modeling and automation, through using the types of logical systems mentioned in note 53 supra, there is no suggestion here that this goal can be achieved easily.

Ultimately, another goal would be to link the application of legal rules to particular cases through a logical assessment of the evidence, using common controlled vocabularies or "ontologies." See, e.g., Barry Smith et al., The OBO Foundry: coordinated evolution of ontologies to support biomedical data integration, 25 NATURE BIOTECHNOLOGY 1251-1255 (2007) (available at: http://www.nature.com/nbt/journal/v25/n11/full/nbt1346.html).

${ }^{58}$ Vaccine Rule 20(a) of the United States Court of Federal Claims. 
Vern R. Walker, Designing Factfinding...

admitted into the legal record, or what types of evidence the factfinder must consider irrelevant when deliberating on certain findings specified in the substantive rule tree, or what standard of proof the factfinder must use. Such evidentiary rules are obviously important in coordinating accurate factfinding, and the next section of the paper will discuss several important types.

\section{B. Examples of Evidentiary Process Rules}

Evidentiary process rules govern various aspects of the evidence assessment process. By stating rules governing factfinders in evidence assessment, they provide a mechanism for judicial oversight of the factfinding process. This section of the paper will briefly discuss and illustrate six types of evidentiary rules - rules about admissibility of evidence, legal sufficiency of evidence, relevant factors, standards of proof, presumptions, and conclusive evidence.

\section{Rules on Admissibility of Evidence}

Some evidentiary rules define conditions under which proffered evidence is to be allowed into the evidentiary record, and thus govern decisions of the presiding official about admitting proffered evidence into the record. As a general baseline, all evidence that is relevant to proving or disproving some issue of fact in the case is admissible into the record, and any evidence that is not relevant is not admissible. ${ }^{59}$ The definition of "relevant" in this context is that the evidence can play a logical role in the reasoning that makes a proposition more probable or less probable. ${ }^{60}$ But in addition to the

\footnotetext{
59 See U.S. FEDERAL RulE OF EVIDENCE 402.

60 See U.S. FEDERAL RulE OF EVIDENCE 401.
} 
Opinio Juris in Comparatione, Vol. 3/2009, Paper n. 1

condition of relevance, evidentiary rules may place other conditions on admissibility. Examples from the evidence law governing U.S. federal courts are the complicated rules about excluding "hearsay" evidence, which is defined as "a statement, other than one made by the declarant while testifying at the trial or hearing, offered in evidence to prove the truth of the matter asserted." ${ }^{.61}$ In establishing the VICP, however, Congress opted for "a less-adversarial, expeditious, and informal proceeding for the resolution of petitions," and directed the Court of Federal Claims to promulgate rules that "include flexible and informal standards of admissibility of evidence." ${ }^{\prime 62}$ As a consequence, Vaccine Rule 8(c) provides:

In receiving evidence, the special master will not be bound by common law or statutory

rules of evidence. The special master will consider all relevant and reliable evidence, governed by principles of fundamental fairness to both parties. ${ }^{63}$

This rule replaces the Federal Rules of Evidence with three conditions governing admissibility, and generates the possibility of case-law interpretation of such terms as "relevant," "reliable," and "fundamental fairness" in the context of vaccine compensation petitions.

\section{Rules on Legal Sufficiency of Evidence}

Some evidence-assessment rules address the totality of evidence admitted into the record that is relevant to proving or disproving a particular issue to be decided. Such rules establish conditions for the minimum amount and quality of evidence needed to prove a particular proposition - that is, the minimum evidence that a reasonable factfinder would need in order to find in favor of the party with

\footnotetext{
${ }^{61}$ U.S. Federal Rules of EvidenCE 802, 801(c). See generally U.S. FEDERAL Rules OF EvidenCE 801-807.

6242 U.S.C. \ 300aa-12(d)(2)(A) \& (B) (2006).

${ }^{63}$ Vaccine Rule 8(c) of the United States Court of Federal Claims.
} 
Vern R. Walker, Designing Factfinding...

the burden of persuasion on that proposition. Such rules therefore create minimum conditions for rational factfinding on such an issue. Sufficiency-of-evidence rules could be general, covering a wide variety of proceedings, or they could be specific to a particular type of proceeding and strike a very particular balance of epistemic and non-epistemic objectives.

There are many examples of legal sufficiency rules within the VICP cases. Some evidenceassessment rules state that certain types of evidence are insufficient to support a finding, thus giving the opposing party a basis for a ruling against the proponent of the proposition. For example, the Federal Circuit has determined that, in establishing causation-in-fact in off-Table vaccine cases, a temporal association of the onset of injury with the vaccination is, by itself, insufficient evidence of causation. ${ }^{64}$ Nor is it sufficient to establish a mere similarity between a petitioner's injury and an injury listed on the Vaccine Injury Table. ${ }^{65}$ In other words, in order for a special master to find causation in fact, there must be evidence in the record establishing more than mere temporal association or mere similarity of injury.

On the other hand, evidence-assessment rules might positively state what kinds of evidence are legally sufficient, thus giving the proponent of the proposition a defense against an argument that the available evidence is insufficient. For example, the Federal Circuit has held that "causation [in fact] can be found in vaccine cases based on epidemiological evidence and the clinical picture regarding the particular child without detailed medical and scientific exposition on the biological mechanisms." ${ }^{96} \mathrm{~A}$ petitioner or a special master can use this evidentiary rule as a defense against a claim by the Secretary that the evidence is legally insufficient.

\footnotetext{
${ }^{64}$ Grant v. Secretary of Health and Human Services, 956 F.2d 1144, 1148 (Fed.Cir. 1992).

${ }^{65} \mathrm{Id}$.

${ }^{66}$ Knudsen v. Secretary of Health and Human Services, 35 F.3d 543, 549 (Fed.Cir. 1994).
} 
Opinio Juris in Comparatione, Vol. 3/2009, Paper n. 1

In both situations (rules that evidence is insufficient or sufficient), such rules give reviewing courts the means to set aside the finding of a factfinder (and in particular, the finding or ruling of a special master). Whether or not these evidentiary rules are satisfied in the particular case is an issue of law, not an issue of fact. ${ }^{67}$ This means that a reviewing court decides the issue de novo, without deference to the factfinder or any lower tribunal.

\section{Relevant-Factor Rules}

Some evidence-assessment rules establish, as a matter of law, which factors a factfinder must consider (compulsory factors) or may consider (permissive factors) in making a finding on a particular type of proposition. If the factfinder ignores compulsory factors, then a reviewing court should set aside the finding as being arbitrary and capricious. (Moreover, if there is no evidence at all in the record on a particular compulsory factor, then the evidence should be ruled to be legally insufficient.) As an example of compulsory factors, the statute establishing the VICP directs that a special master

... shall consider, in addition to all other relevant medical and scientific evidence contained in the record -

(A) any diagnosis, conclusion, medical judgment, or autopsy or coroner's report which

is contained in the record regarding the nature, causation, and aggravation of the petitioner's illness, disability, injury, condition, or death, and

(B) the results of any diagnostic or evaluative test which are contained in the record and the summaries and conclusions. ${ }^{68}$

\footnotetext{
${ }^{67}$ See Fleming James, Jr., Geoffrey C. Hazard, Jr. \& John Leubsdorf, CiviL ProCEDURE $\int 7.19$ (Fourth Edition; Little, Brown and Co. 1992).

6842 U.S.C. \ 300aa-13(b)(1) (2006).
} 
Vern R. Walker, Designing Factfinding...

The statute is clear, however, that such evidence is merely a factor to be considered, and is not "binding" on the special master as factfinder. ${ }^{69}$

On the other hand, appellate courts often create rules establishing permissive factors when they issue judgments in particular cases. For example, the Federal Circuit has underscored the relevance and probative value of medical opinions in certain circumstances, ${ }^{70}$ as well as medical records and medical opinions by physicians who have actually treated the injured person. ${ }^{71}$ When permissive factors are involved, then a party is entitled to proffer evidence of that type, and arguments based on that evidence are clearly relevant as a matter of law.

\section{Standards of Proof}

Standards of proof are evidentiary rules that instruct the factfinder as to when the strength or probative value of the relevant evidence warrants or supports a finding of "fact" on the issue to be decided. For example, under the preponderance standard of proof applicable in the VICP cases $^{72}$ (which is also the standard applicable generally in U.S. civil litigation ${ }^{73}$ ), the factfinder is to make a

69 See id.

${ }^{70}$ Capizzano v. Secretary of Health and Human Services, 440 F.3d 1317, 1326 (Fed.Cir. 2006) (stating that "if close temporal proximity, combined with the finding that hepatitis B vaccine can cause RA [rheumatoid arthritis], demonstrates that it is logical to conclude that the vaccine was the cause of the RA (the effect), then medical opinions to this effect are quite probative").

${ }^{71}$ Id., 440 F.3d at 1326 (stating that "medical records and medical opinion testimony are favored in vaccine cases, as treating physicians are likely to be in the best position to determine whether 'a logical sequence of cause and effect show[s] that the vaccination was the reason for the injury'," quoting Althen, 418 F.3d at 1278).

7242 U.S.C. \300aa-13(a)(1) (2006).

${ }^{73}$ James, Hazard \& Leubsdorf, supra note 67, at $\int 7.5$. 
finding in the direction in which the "greater weight of the evidence" or its "convincing force" points (i.e., either for or against the proposition to be proved).$^{74}$ Under this standard, a finding should mean that the factfinder has determined the proposition to be "more probably true than false." 75

The Federal Circuit has also determined that Congress intended the VICP to be a system "in which close calls regarding causation are [to be] resolved in favor of injured claimants." ${ }^{, 76}$ Some special masters have interpreted this as meaning that " $50 \%$ and a feather" is enough weight of evidence to warrant a finding, ${ }^{77}$ and the Federal Circuit has upheld findings made under this understanding. ${ }^{78}$

The Federal Circuit has also stated that "the purpose of the Vaccine Act's preponderance standard is to allow the finding of causation in a field bereft of complete and direct proof of how vaccines affect the human body." ${ }^{79}$ Thus, circumstantial evidence is expected and often legally sufficient.

Rules regarding the standard of proof provide guidance to factfinders in assessing the evidence, and provide some leverage to reviewing courts in overseeing the results of factfinding.

\section{Rules about Presumptions}

\footnotetext{
${ }^{74}$ Vern R. Walker, Preponderance, Probability and Warranted Factfinding, 62 BroOKLYN L. REV. 1075, 1076 (1996); James, Hazard \& Leubsdorf, supra note 67 , at $\$ 7.14$.

75 Walker, supra note 74, at 1076.

${ }^{76}$ Althen, supra note 24, 418 F.3d at 1280.

77 E.g., Colon v. Secretary of Health and Human Services, 2007 U.S. Claims LEXIS 13, at *47 (2007) (stating that "[u]nder the Vaccine Act, a petitioner is not required to prove his case by medical certainty but only by a preponderance of the evidence, which this Court has described as 50\% and a feather").

78 See Pafford v. Secretary of Health and Human Services, 451 F.3d 1352, 1360, 1361 (Fed.Cir. 2006) (the majority upheld the decision of the special master, and the dissent stated that "the Special Master "painstakingly looked for the feather in Petitioners' argument that would tip the scales' as to causation in fact," that the special master did not find such additional evidence, and that "[t]he majority holds that this was proper").
}

${ }^{79}$ Althen, supra note 24, 418 F.3d at 1280. 
Vern R. Walker, Designing Factfinding...

In terms of purely logical form, a presumption is a conditional proposition that states that if some condition is true, then another proposition is true. Presumptions therefore have the same logical form as legal rules. Moreover, some presumptions are "conclusive" or "irrebuttable," having the form "if $A$, then necessarily $B . " 80$ Such presumptions are sometimes called "presumptions of law," because, as a matter of law, "if the trier of fact finds $A$ it must also find $B . "{ }^{\prime 81}$ Such presumptions function very much as rules of law function, and may simply be ways of stating substantive legal rules.

Other presumptions, however, are "device[s] for allocating the burden of production," and some regard the word "presumption" as referring properly only to such a rule. ${ }^{82}$ Such a rule, often called a "rebuttable presumption," operates as follows: "If $B$ is presumed from $A$, then on a showing of $A, B$ must be assumed by the trier in the absence of evidence of non- $B .{ }^{\prime 83}$ In other words, if $A$ is proved, then $B$ is presumed to be proved also, unless an opposing party produces sufficient evidence and persuades the factfinder to the contrary. An example from the VICP is the "statutorily-prescribed presumption of causation" for Table injuries ${ }^{84}$ When a petitioner establishes that there has occurred a vaccination with a vaccine listed on the Table, as well as an injury that is listed on the Table in association with that vaccine and whose onset occurred within the time period listed on the Table, then "the law presumes" that the vaccine caused the injury, and the petitioner is "presumptively entitled to

\footnotetext{
80 See James, Hazard, and Leubsdorf, supra note 67, \$ 7.17 at p. 346.

${ }^{81} I d$

${ }^{82}$ Id., $\int 7.17$ at pp. 346-47. There is also a distinction between presumptions that shift only a burden of producing or going forward with evidence, and presumptions that shift both the burden of production and the burden of persuasion. This distinction is not needed, however, in order to illustrate how presumptions can coordinate decentralized factfinding.

${ }^{83} \mathrm{Id}$. at 347.

84 Althen, supra note 24, 418 F.3d at 1278; 42 U.S.C. \ 300aa-11(c)(1)(C)(i) (2006).
} 
Opinio Juris in Comparatione, Vol. 3/2009, Paper n. 1

compensation." ${ }^{\$ 5}$ Such a showing does not end the case, however. "If petitioner can make such a showing, causation is presumed," and proving the remainder of the prima facie case will entitle the petitioner to compensation, unless the government "can show to a preponderance that a 'factor unrelated' to the vaccine was the actual cause of petitioner's injuries." 86

Either kind of presumption can assist a rule-making authority in overseeing and coordinating decentralized factfinding, but a rebuttable presumption does so by establishing an evidentiary rule governing the reasoning of the factfinder in the evidence assessment process.

\section{Rules about Conclusive Evidence}

Finally, there may be legal rules about when the totality of relevant evidence on a proposition is or is not (may be or may not be) conclusive in proving that proposition. If legal sufficiency is the minimum amount or quality of evidence needed (as a matter of law) for any reasonable factfinder to make a finding, then conclusive evidence is the amount or quality of evidence that would compel (as a matter of law) any reasonable factfinder to make a finding. In most cases, the quality or strength of evidence falls somewhere between these two extremes, and reasonable factfinders can differ over which inferences to draw and what findings to make. But just as legal authorities can make lower-bound rules for rational evidence assessment (legal-sufficiency rules), they can also make upper-bound rules (compulsory-evidence rules).

In practice, a reviewing court creates such rules when it determines that the evidence in the record is so strong that the court itself can hold, as a matter of law, that a finding must be made for the

\footnotetext{
85 See Knudsen, supra note 66, 35 F.3d at 547.

${ }^{86}$ Whitecotton v. Secretary of Health and Human Services, 81 F.3d 1099, 1102 (Fed.Cir. 1996).
} 
Vern R. Walker, Designing Factfinding...

party who has the burden of persuasion on that issue. In such a situation, when the reviewing court decides the issue of fact as a matter of law, it is saying that any reasonable factfinder must assess the evidence in this particular record the same way. Due to the peculiarity of institutional structure in the VICP, such decisions would be rare. This is because, when the Court of Federal Claims sets aside a finding of fact of a special master as being arbitrary and capricious, the court is entitled as factfinder to make its own findings of fact. ${ }^{87}$ But then these substitute findings are not rulings of law, but simply findings of fact. So in the VICP system we would find rules of conclusive evidence only if the Federal Circuit sets aside the findings of the Court of Federal Claims as being "plain error" and decides substitute findings without a remand.

\section{Conclusion}

This paper has addressed the task of ensuring consistent, accurate and evidence-based factfinding concerning compensation for medical accidents in cross-border healthcare, without imposing on participating jurisdictions a centralized factfinding institution. Using examples from the National Vaccine Injury Compensation Program in the United States, the paper has examined the allocation of particular logical tasks to different institutional structures (such as administrative rulemaking, omnibus proceedings, and expert committees), and also the use of legal rules as coordinating devices (such as sufficiency-of-evidence rules and relevant-factor rules).

This brief overview of logical functions and possible institutional allocations provides a framework and set of tools that may be useful as the European Community faces the task of ensuring

\footnotetext{
87 See supra text accompanying note 39.
} 
Opinio Juris in Comparatione, Vol. 3/2009, Paper n. 1

"safe, high quality and efficient cross-border healthcare." For example, an expert agency could assemble medical evidence for the legal record and issue opinions or findings on generic issues of fact concerning medical knowledge, much as the European Food Safety Authority does for food science. ${ }^{88}$ And the European Court of Justice could establish substantive and process legal rules (including evidenceassessment rules) binding on medical-accident tribunals in Member States, much as the Court has in other areas affecting public health. ${ }^{89}$ It is not the task of this paper, however, to argue for any particular institutions or legal rules in the area of cross-border healthcare. Rather, the goal has been to provide insights on how factfinding can be transparent, evidence-based, and coordinated, as well as (presumably) accurate, so that all potentially affected parties can be confident that decentralized compensation systems are achieving their epistemic and non-epistemic goals.

88 See European Parliament and Council Regulation 178/2002/EC, 2002 OJ L31/1 (laying down the general principles and requirements of food law, establishing the European Food Safety Authority and laying down procedures in matters of food safety); Health and Consumer Protection Directorate-General, "European Food Safety Authority (EFSA) Introduction," European Food Safety Authority, http://ec.europa.eu/food/efsa en.htm; European Food Safety Authority, "EFSA Science," European Food Safety Authority, http://www.efsa.europa.eu/EFSA/efsa locale$\underline{1178620753812 \text { home.htm. }}$

89 See, e.g., Commission v. Denmark, C-192/01, [2003] ECR I-9693, para. 46-53 (establishing, in the context of free movement of goods and protection of human health, Community rules governing the burden on Member States to show that the marketing of products poses a real risk to human health, including rules concerning the sufficiency of supporting evidence). 